\title{
Trends and determinants of female age at first marriage in Sub-Saharan Africa (1990-2014): What has changed?
}

\author{
Emmanuel O. Amoo \\ Department of Demography and Social Statistics, College of Business and Social Sciences, \\ Covenant University, Ota, Ogun State, Nigeria \\ emma.amoo@covenantuniversity.edu.ng
}

\begin{abstract}
The study analysed trends and determinants of female age at first marriage in Ghana, Kenya and Zambia using DHS datasets across defined survey horizons: 1990-1999, 2000-1999 and 2010-2014. The data analysis employed frequency distribution, cross tabulation and Cox proportional regression techniques. The results revealed female median age at first marriage as 17. The result showed a reduction in the proportion marrying at age $\leq 17$ between 1990 and 2014 by $9.8 \%$ (Ghana), $6.2 \%$ (Kenya) and $7.2 \%$ (Zambia). Women with tertiary education and rich households had lower hazard ratio to marry at age $\leq \mathrm{I} 7$ compared with those without education and from poor households (HR: 0.39, Cl: 0.0.36-0.43) and (HR: $0.86, \mathrm{Cl}: 0.8 \mathrm{I}-0.90)$ respectively. The study supports the use of child-marriage market model to heighten female age at first marriage through access to tertiary education. The boost in female education could be harnessed for sustainable development through provisions of job opportunities.
\end{abstract}

Keywords: Female age at first marriage, child-marriage market, sub-Saharan Africa

\section{Introduction}

Age at first marriage is a crucial population dynamic in Africa that is associated with age at which marriageable individuals of opposite sexes are connected, it is the age at which family is formed, and age at which children are expected to be born in subSaharan Africa. Also, age at first marriage is a license for exposure to sexual relationship and indirect vulnerability to its social and health trajectories such as HIV/AIDS, STIs, parenthood (motherhood/fatherhood) and so on (Bongaarts, 2007; Garenne, 2004; Garenne, Leclerc, \& Matthews, 20II; Gupta, 20II; Mensch, Grant, \& Blanc, 2006; Mensch, Singh, \& Casterline, 2005). However, female age at first marriage differs from culture to culture, from one region to region, it varies among groups and from wealth/prosperity to poverty or recession time (Bongaarts, 2007; Glick \& Landau, 1950; Indongo \& Pazvakawamba, 2015; Odimegwu, Bamiwuye, \& Adedini, 2015). The fluidity of female age at first marriage as well as its association with every facet of life, economic and development makes continuous analysis of female age at first marriage inexhaustible in research.

In the world today, female age at first marriage is more diverse and has created two polarities among countries. At one end of the spectrum are countries with late marriages, small family sizes and women's participation in labour force, e.g. China, Hong Kong, Japan, Taiwan, Thailand and South Korea, in addition to most countries of America and Europe (Jones,

http://aps.journals.ac.za
2012; Keller, 1973; Murray, King, \& Crowe, 2016). At the other extreme, are countries with, not only early marriages, but also girl-child marriages, large family sizes and unequal gender inequalities with countries like Nigeria, Democratic Republic of Congo, Tanzania, Uganda, Niger, Afghanistan, Burkina Faso as examples (Isiugo-Abanihe, 1995; UNICEF, 20I4a; World Health Organization, UNAIDS, \& UNICEF, 20I I; Zwang, 2004). Countries in the latter group are overwhelmed with youth/young persons, and the children share more than one-third proportion of the population (United Nations, 2014; You, Hug, \& Anthony, 2015). An average of 4I,000 girls are married off every day (UNICEF, 20I4b), and in the next decade over I40 million girls are likely to be married before they become 18 (UNICEF, 20I4b). Till date, female early marriage is traditionally acceptable and predominant in certain communities while late marriages are increasingly emerging in others (Indongo \& Pazvakawamba, 2015; Zwang, 2004).

Marriage is sacrosanct in African settings, it follows cultural process, but mostly characterised by early age, polygamy practices and multiple births (Awusabo-Asare \& Annim, 2008; Bingenheimer, 2010; Delius \& Glaser, 2004; Ikpe, 2004; Reda \& Lindstrom, 2014). However, by description and in accordance to Article I of the convention of the right of the child, female early marriage refers to any marriage (formal marriages and informal unions) 
carried out below the age of 18 or involving a girl younger than 18 years that lives with a partner as if married (UNICEF, 2005). A girl-child marriage is therefore conceptualised as any formal or informal marriage/union in which a girl younger than 18 years lives with a partner, whether with or without formal registration, under civil, religious or customary laws (Alcalá \& Leidl, 2006; UNICEF, 2005). Studies have confirmed that in Africa settings, this type of marriage is predominant (Mensch et al., 2006, 2005; Pettifor, Van Der Straten, Dunbar, Shiboski, \& Padian, 2004; UNICEF, 200I). Specifically, in the traditional Africa settings, the girl-child virginity is extolled as virtue that procures honour and good name to the family, hence, the drive to give away a little-child for marriage before her real exposure to pre-marital sexual activities (Mensch et al., 2006; UNICEF, 200I). More than one-quarter of 75 million women aged 20-24 that enters their first marriages or union before they reach 18years of age are from Africa (World Vision, Henderson, \& Jones, 2016). Over three out of five sub-regions of Africa were reported to have higher rates of child-marriage than the global average of $26 \%$ (United Nations Children's Fund [UNICEF], 20I5). The proportion of child-marriage stands at $42 \%, 40 \%, 37 \%, 26 \%$ in Western, Central, Eastern and Southern Africa, respectively (United Nations Children's Fund [UNICEF], 20I5).

There have been renewed interventions across the globe to address the issue of early marriage, especially the girl-child marriage with a keen focus on sub-Saharan Africa among other developing countries. Prominent among these interventions is the elimination of child, early and forced marriage as enshrined in the United Nations Human Rights Council and the sustainable development Goals (SDGs) (African Union, 2015a, 20I5b, UNICEF, $201 \mathrm{I}, 20 \mathrm{l} 4 \mathrm{~b})$. There are also numerous international and national organisations that are creating awareness on the dangers inherent in early child-marriage and early motherhood. Specifically, there are focuses on women empowerment (that include free basic education for girls) and sexual reproductive rights which are geared towards lowering the rates of child brides (Adebowale \& Palamuleni, 2014; United Nations Population Fund [UNFPA], 2004). These interventions and agendas could also be regarded as offshoots of International Conference on Population and Development (1994), the Beijing conference of 1995, the MDGs (2000), SDGs (20I5), Vision-2020 (International Planned Parenthood Federation) and the African Union 'Agenda 2063' and they are all supportive of girl's maturity before exposure to sex, marriage and childbearing (International Center for Research on Women [ICRW], 20I5; Mensch et al., 2006, 2005; UNFPA, 20I3; Wahhaj, 20I5; Walker et al., 20/3). Today, there are also emerging laws and regulations against human-trafficking and application of criminal laws to under-age sex, child-bride and sex work (Chersich et al., 20l3).

Currently, in the developing countries, more than one-third of girls are married before the age of 18 , and one out of every nine girl-child marry before the age of 15 (International Center for Research on Women [ICRW], 20I5; Mensch et al., 2006, 2005; United Nations Population Fund [UNFPA], 2012; Wahhaj, 20I5). Precisely in Africa, more than $42 \%$ of women aged 15-24 had married before reaching the age of 18 (UNFPA 2005; UNICEF, 20I4). Despite the global decline in early marriage rate that has been achieved with considerable contributions from the developed countries, and notwithstanding the numerous initiatives to achieve the same reduction in developing countries (Jones, 20I2; Keller, 1973; Lloyd and Mensch, 2008), sub-Saharan Africa still remain the largest contributor to under-age marriages world-wide (Budlender, Chobokoane, \& Simelane, 2004; Gurmu, \& Etana, 20I4; GyepiGarbrah, Nichols, \& Kpedekpo, 1985; International Center for Research on Women [ICRW], 20I5). For example, in Nigeria, $49 \%$ of women aged 25-49 years were married by age 18 while $61 \%$ were married by age 20 (Bigombe \& Khadiagala, 2003; Machiyama, 20I I; National Population Commission (NPC) [Nigeria] \& ICF International, 2013; Population Reference Bureau [PRB], 20I5). The median age at first marriage increased in Ethiopia from 17 to 18 years between 2005 and 201 I (Reda \& Lindstrom, 20I4). In a study conducted by Garenne (2004) using DHS and Women Fertility Survey data across 32 Africa countries, the median age at first marriage increased from 17.7 in 1925/1929 to 18.7 in 1975/1979, representing an increase of approximately $5 \%$ in five decades (Garenne, 2004; Measure DHS, 2008). The reported median age at first marriage for Ghana was 18.7 (1993) and 21.0 (2003/2008), Kenya was 18.3 (1993) and 20.2 in 2009, while Namibia recorded 24.8 years in 1992 (Garenne, 2004; Measure DHS, 2008; United Nations, Department of Economic and Social Affairs, Population Division, 2014).

\section{Theoretical framework}

The study is premised on the theoretical model of the child-marriage market that explains how the practice of child-marriage could be discontinued (Wahhaj, 2015; Goody, 1990; Mogghadam, 2004; Amin \& Bhajraha..20II). The model positions that the practice of child-marriage could be sustained in the presence of inherent preferences for young brides, where younger girls are perceived as good quality and suitability for marriage (Wahhaj, 20I5). 
The model, as applied in other studies, indicated that in any environment, where the younger the girl-child, the more opportunity the family has to claim purity and receive higher bride price (Bhat \& Halli, 1999; Moghadam, 2004; Rezai-Rashti \& Moghadam, 201I; Wahhaj, 20I5), the higher will be the prevalence of child-bride. Thus, aiming at the interventions which could increase the opportunity cost of early marriage would be potentially suitable for reduction in girlchild marriage (Wahhaj, 2015). The model in its simplicity form, indicated that, the various opportunities provided for girls other than marriage would impact on the marriage market in two ways: (I) it will provide opportunity for the family to negotiate higher bride price (having expended resources on their daughters, especially in terms of money spent on her education) and thereby making it more expensive and less attractive for men seeking young brides; (2) it will provide opportunity for the girl-child to turn down the marriage offer as a result of her engagement in schooling or skills acquisition (Wahhaj, 2015). In addition, since all initiatives from international organisations, and NGOs (national and externally) are tailored towards investments on interventions that could raise awareness about the negative effects of girl-child marriage, the programmes could encourage parents to postpone marriage for their children (Wahhaj, 2015). The programmes could also expose the girl-child to development opportunities such as acquisition of new skills, equipping them with knowledge and understanding of their rights, and the dangers inherent in early motherhood (Wahhaj, 20I5). The above notwithstanding, even if these interventions failed to discourage parents in child-marriage, the fact that the expansion of non-marriage related opportunities for girls could enhance the girls enlightenment to turn down marriage offers or negotiate higher bride price will discourage prospective grooms or enhance more waiting time and be a sufficient opportunity to heighten age at first marriage.

At the societal levels, the model could also be linked to various propositions in other studies that have identified increasing age at first marriage with potential to shorten the length of exposure to childbearing, capable of engendering smaller family sizes; and at the macro level, reduce the population sizes (Bongaarts, 1983; Hindin \& Fatusi, 2009; Huq \& Cleland, 1990; Isiugo-Abanihe et al., 2012; Islam \& Islam, 1993; Mensch et al., 2005). In countries where substantial proportions marry early, such countries have tendency for high birth rates, and larger family sizes. However, where marriage is delayed, the time of exposure to pregnancy reduces, fertility could be limited and family size becomes smaller, more time could be gained for productive economic activities. Also, it could also reduce the degree of girl-child's vulnerability to STIs/HIV and AIDS. While several studies have documented the social and economic implications of age at first marriage (Andreev, Kantorová, \& Bongaarts, 2013; Bongaarts, 2010; Bongaarts \& Sinding, 20I I; Okogu, 20 I ; Psaki, 20 I5; Zwang, 2004), marriage and religiousity (Odimegwu, 2005); analytical work on the regional variations in age patterns of marriage and complexity surrounding its determinants are relatively scanty in the literature. The study therefore conducted an analysis of female age at first marriage in Ghana, Kenya and Zambia to underscore its trends and changes in its determinants covering the DHS datasets between 1990 and 2014 . The idea behind this study is to assess the changes in the determinants of female age at first marriage in sub-Saharan Africa. The results could enhance making appropriate suggestions towards the delivery of post2015 sustainable development agenda especially through the reduction in early/child-marriage and its associate trajectories such as infant/maternal morbidities and mortality and, girl-child vulnerability to STIs/HIV and AIDS (African Union, 2015a; ICSU \& ISSC, 20I5).

\section{Data sources and methods \\ Research design}

The data for this study were from national representative datasets of Demographic Health Survey (DHS). The period of 1990 to 2014 was chosen to cover the beginning of uniform DHS dataset (1990s) across sub-Saharan Africa and the latest round of the survey. The surveys were group into 3-Waves: Wave I covering surveys within 1990 and 1999; Wave 2 covered 2000-2009 and data for 2010 to 2014 were used in Waves 3 . Only the women recode-datasets were used and the respondents were women in their reproductive age (15-49 years). The selection of the countries was guided by availability of at least three datasets that fall within the waves defined for this study. However, among the group of countries whose survey years fall into these waves, three countries were selected randomly across sub-Saharan African with each one representing the Eastern, Western, Southern parts of the region. Thus, Ghana (Western), Kenya (Eastern) and Zambia (Southern) were selected. Also, attempt was also made to minimize bias by placing attention on the selection of dataset from close survey horizons across the countries. That is, within one horizon/wave, the data years are not too wide apart. This is to ensure that the data years are relatively close to avoid obvious variations within each wave. Specifically for Ghana data, 1998, 2008 and 2014 datasets were selected. Kenya's datasets included 
1998, 2009 and 2014 while Zambia sets of data covered 1996, 2007 and 2014. The total sample covered was 98,137 women.

\section{Data measurements and analysis}

The period of data collection guided the data grouping and analysis. Data belonging to 1990-1999 was recoded as wave I, dataset between 2000 and 2009 as wave 2, while the last surveys between 2010 and 2014 were grouped as wave 3 . All the datasets were merged together to create a general data file. From this general file, a new data file (containing wave I, wave 2 and wave 3 data) but with only variables of interest was created as the data file for this study.

Three levels of analysis were adopted, namely: univariate, bivariate and multivariate. The profile of the respondents and other details about the selected variables were presented using frequency tabulations, with basic averages like median computed (where applicable). The analyses were done by splitting according to the waves, and by countries which helped to reveal the trends and the changes among the selected variables. In the multivariate analysis, Cox proportional hazard regression analysis was employed. The Cox hazard regression model permits the time to event analysis of female age at first marriage. The rates of entry into union were estimated using the Kaplan-Meier method while the Log-rank test was used to compare age at entry into first union/marriage between three waves. Ever married was the outcome of interest while 'never married' were censored at their current age at the time of the survey. The net effect of each of the explanatory variables was estimated using hazard ratio with $95 \%$ confidence interval having taken the $5 \%$ as putative marginal errors effect. The explanatory variables were educational attainment, religious affiliation, wealth status, occupation and usual place of residence. Bivariate analysis was also computed to underscore the distribution of selected respondent's characteristics by age at first cohabitation. The age at first cohabitation was presumed as the age of first union or actual marriage. The variable was recoded into (I) age $\leq I 7$ years and (2) 18 years and above.

In this study, the Cox hazard regression employed considered how the hazard of experiencing early marriage $(\leq 17)$ among respondents with certain characteristics is different from the hazard of experiencing female early marriage in the reference category. In the interpretation of the results, a hazard ratio of 0.4 , (for example), means the group concern has a $60 \%$ lower hazard than the reference category (Lehrer, 2008; Pettifor et al., 2004). This has also been interpreted and used in different studies
(Gurmu \& Etana, 20I4; Lehrer, 2008; Mubiru, Atuhaire, Lubaale, \& Wamala, 2016; Pettifor et al., 2004). Also, a hazard ratio of 1.4 would imply that the group has $40 \%$ higher hazard than the reference category. The statistical software used for modeling is Stata/SE version 14. In the Cox proportional hazards regression analysis, both the marital status and the age at marriage were combined to generate the probability of marrying at a particular time, which is the outcome variable. This is termed the hazard. The general hazard model equation is denoted as:

$\log \frac{H(t)}{\mathrm{H}_{0}(t)}=\beta_{1} X_{1}+\beta_{2} X_{2}+\cdots+\beta_{n} X_{n} \ldots \ldots . .$. (1)

Where X's are the explanatory variables, $H_{0}(t)$ is the baseline hazard at 'time_t', representing the hazard for a person with the value ' 0 ' for all the explanatory variables. The $\mathrm{H}(\mathrm{t}) / \mathrm{HO}(\mathrm{t})$ is regarded as the hazard ratio while the coefficients ( $\beta \mathrm{s}$ ) are estimated by Cox regression.

\section{Ethical consideration}

The data used in this study were secondary data collated by MEASURES DHS, ICF Macro, Calverton, Maryland, USA. The data were made available with the respondents identifiers completely removed. The survey exercise and the data were approved by Institutional Review Board of ICF Macro, and also by country-specific ethics-related committees. International standards of data collections were duly employed and all participants gave informed consent before their participation. Information collected was also accorded the right confidentiality. For this study, the author registered and applied for the use of the data and adequate permission was given before the data were downloaded and analysed.

\section{Results}

The profiles of women covered in the study as obtained in the univariate analysis are indicated in Table I. The total samples of 98,137 women covered were distributed into waves by the year of data collection. Although, the sample distribution among all countries selected was not uniform, so also was the distribution within each wave. However, analysis was done by proportion for uniformity and data consistency. The Kaplan-Meier female median age at first marriage was 17 year; the survival time revealed that $25 \%$ of the sample married at age $\leq 17$ year while $75 \%$ had married at 23 years. The age distributions show a downward decline from the higher proportion at the younger ages to lower proportion at the older ages. The younger women in the age group 15-24 constituted more than one-third of the sample. From Ghana data, the percentage of women in ages $\leq 24$ years rose from $36.7 \%$ in the base-year, to $38.8 \%$ in $2000 / 2009$ and decreased to $35.4 \%$ in $2010 / 2014$ (Tablel). The distribution of http://aps.journals.ac.za 
women sampled in Kenya exhibited a gradual diminishing trend across the age categories from I519 up to age $45-49$.

The proportion of individuals without formal education decreased considerably in Ghana from $35.5 \%$ in 1998 to $25.3 \%$ in 2008 and $24.3 \%$ in 2014 . In Kenya, the number increased by $1.9 \%$ between 1998 and 2008 but later decreased to $13.5 \%$ in 2010/2014. While women with secondary education in Ghana was the highest among other education groups, the proportion also increased across the years surveyed (|990-20|4). Primary education for women witnessed consistent decline in Kenya 59.9\% (1990s) to $52.2 \%$ during in 2000/2009 and decreased again by $2.0 \%$ in $2010 / 2014$. Educational attainment increased from primary to secondary education for countries like Kenya and Zambia but declined considerably at the tertiary level. Overall, the percentage of women with secondary education and above was relatively small across all the three countries. The percentage of women without formal education in Ghana doubled that of other countries.
The proportion of women not working was about a third of total women interviewed in Ghana. This proportion only decreased in 2008 by almost 10\% when compared with 1998 results. It further declined by $15 \%$ in the year 2014 . A great variation exists between this result and that of Kenya and Zambia, where more than $60 \%$ of the women interviewed were not working (i.e. they were either full-time housewives or unemployed) as at the time of the survey. The professional, the skilled and unskilled manual workers were relatively less than $6 \%$ of the women in each survey and across the selected countries. In the first wave (1990-1999), the occupations that had the highest proportion of women in Ghana were farming (39.2\%) and the clerical/sales jobs $(22.3 \%)$. In Kenya, the highest ranked job in 1998 was clerical jobs (36.6\%), which later shifted to farming in 2008 and 2014. Farming has consistently been the major occupation for women in Zambia. One in every five women interviewed in 2014 were engaged in farming business in Ghana, Kenya and Zambia.

Table I. Demographic profile of women across selected Sub-Saharan Countries

\begin{tabular}{|c|c|c|c|c|c|c|c|c|c|}
\hline \multirow{2}{*}{ Selected Country } & \multicolumn{3}{|c|}{ Wave I (1990-1999) } & \multicolumn{3}{|c|}{ Wave 2 (2000-2009) } & \multicolumn{3}{|c|}{ Wave $3(2010-20 \mid 4)$} \\
\hline & $\begin{array}{c}\text { Ghana } \\
\mathrm{N}=4 \\
843\end{array}$ & $\begin{array}{c}\text { Kenya } \\
N=7 \\
881\end{array}$ & $\begin{array}{c}\text { Zambia } \\
\mathrm{N}=8 \\
021\end{array}$ & $\begin{array}{c}\text { Ghana } \\
N=4 \\
916 \\
\end{array}$ & $\begin{array}{c}\text { Kenya } \\
N=8 \\
444 \\
\end{array}$ & $\begin{array}{c}\text { Zambia } \\
N=7 \\
146\end{array}$ & $\begin{array}{c}\text { Ghana } \\
N=9 \\
396\end{array}$ & $\begin{array}{c}\text { Kenya } \\
\mathrm{N}=31 \\
079\end{array}$ & $\begin{array}{c}\text { Zambia } \\
\mathrm{N}=16 \\
4 \mid \mathrm{I}\end{array}$ \\
\hline \multicolumn{10}{|l|}{ Age group } \\
\hline $15-19$ & 18.4 & 23.5 & 24.7 & 21.1 & 20.9 & 22.4 & 18.7 & 19.6 & 22.5 \\
\hline $20-24$ & 18.3 & 19.6 & 22.7 & 17.7 & 20.7 & 19.7 & 16.7 & 17.4 & 18.5 \\
\hline $25-29$ & 17.7 & I7. & 16.0 & 16.6 & 16.9 & 19.2 & 16.6 & 19.1 & 17.0 \\
\hline $30-34$ & 13.6 & 12.4 & 13.5 & 12.9 & 14.0 & 14.6 & 14.3 & 14.3 & 14.8 \\
\hline $35-39$ & 12.9 & 12.7 & 9.6 & 13.0 & 11.0 & 10.2 & 13.4 & 12.4 & 12.0 \\
\hline $40-44$ & 10.0 & 8.2 & 7.1 & 9.9 & 8.6 & 7.5 & 11.0 & 9.6 & 8.9 \\
\hline $45-49$ & 9.0 & 6.6 & 6.4 & 8.8 & 7.9 & 6.5 & 9.3 & 7.6 & 6.2 \\
\hline Total & 100.0 & 100.0 & 100.0 & 100.0 & 100.0 & 100.0 & 100.0 & 100.0 & 100.0 \\
\hline \multicolumn{10}{|l|}{ Residence } \\
\hline Urban & 32.7 & 18.6 & 37.4 & 44 & 31 & 44.5 & 49 & 37.4 & 48 \\
\hline Rural & 67.3 & 81.4 & 62.6 & 56 & 69 & 55.5 & 51 & 62.6 & 52 \\
\hline Total & 100 & 100 & 100 & 100 & 100 & 100 & 100 & 100 & 100 \\
\hline \multicolumn{10}{|l|}{ Educational level } \\
\hline No education & 35.9 & 12.8 & 14.6 & 25.3 & 14.7 & 10.4 & 24.3 & 13.5 & 8.3 \\
\hline Primary & 16.8 & 59.9 & 60.3 & 20.3 & 52.2 & 53.2 & 18.6 & 50.2 & 46.6 \\
\hline Secondary & 45.2 & 25.4 & 22.8 & 50.7 & 24.7 & 31.4 & 51.7 & 27.7 & 39.9 \\
\hline Higher & 2.2 & 1.9 & 2.4 & 3.7 & 8.5 & 5.0 & 5.5 & 8.6 & 5.2 \\
\hline Total & 100 & 100 & 100 & 100 & 100 & 100 & 100 & 100 & 100 \\
\hline \multicolumn{10}{|l|}{ Occupation } \\
\hline Not Working & 33.7 & 60.3 & 67.0 & 40.4 & 54.9 & 45.8 & 25.2 & 42.5 & 45.9 \\
\hline Prof/Armed Forces & 2.7 & $\mathrm{I} .5$ & 1.8 & 4.6 & .7 & 2.7 & 4.1 & 0.6 & 2.2 \\
\hline Clerical/Sales/Admin & 22.3 & 36.6 & 2.0 & 2.9 & 5.5 & 7.6 & 35.2 & 6.6 & 20.6 \\
\hline Skilled Manual & 2.0 & 0.4 & 1.8 & 5.5 & 6.8 & 3.5 & 11.2 & 4.7 & 1.2 \\
\hline Farming & 39.2 & 0.1 & 26.9 & 46.3 & 24.3 & 26.1 & 22.9 & 27.9 & 26.1 \\
\hline Unskilled Manual & 0.1 & 1.2 & 0.4 & 0.2 & 7.8 & 14.2 & 1.4 & 17.7 & 4.0 \\
\hline Total & 100.0 & 100.0 & 100.0 & 100.0 & 100.0 & 100.0 & 100.0 & 100.0 & 100.0 \\
\hline \multicolumn{10}{|l|}{ Religion } \\
\hline Christianity & 77.7 & 99.8 & 99.7 & 73.9 & 99.3 & 98.7 & 76.3 & 99.8 & 99.4 \\
\hline
\end{tabular}


African Population Studies Vol 3I, No I, (Supp. 2), 2017

\begin{tabular}{lccccccccc} 
Islam & 14.3 & - & - & 16.9 & - & - & 18.4 & - & - \\
Traditional & 8.0 & 0.2 & 0.3 & 9.2 & 0.7 & 1.3 & 5.3 & 0.2 & 0.6 \\
Total & 100.0 & 100.0 & 100.0 & 100.0 & 100.0 & 100.0 & 100.0 & 100.0 & 100.0 \\
Total & 100 & 100 & 100 & 100 & 100 & 100 & 100 & 100 & 100 \\
\hline
\end{tabular}

Source: Computed from selected DHS datasets of Ghana, Kenya and Zambia (1990-2014)

The cross-tabulation featured only the distribution of socio-demographic variables with respect to cohabitation at age $\leq 17$ years and according to the waves and countries of study. The results of the analysis revealed that, relatively, two-third of the girls that married before they attained age of 18 had below secondary school education. Across all the countries of study, almost $60 \%$ of the women who had only primary education married before they reached 18. However, there was a declining trend across the waves, except in Kenya where the proportion of women without education and those that marrying at lower age remained relatively constant (Table 2).

Although the proportion of respondents tilted towards a particular religion (i.e. Christianity), the proportions of girl-child that marry remained relatively unchanged from what was obtainable in 1990/1999 in terms of religion distribution. The cross-tabulation results in terms of occupation revealed mixed results according to individual country and years of the survey. The proportions of unemployed girls that married in Zambia was $68.5 \%$ in 1990/1999, it was low as $15.6 \%(2000 / 2009)$ but later increased to $40.7 \%$ in $2010 / 2014$. Similar result occurred in Kenya with $63.9 \%, 51.0 \%$ and $71.8 \%$ in 1990/1999, 2000/2009 and 2010/2014, respectively. Opposite trend was obtained in Ghana with $18.8 \%$, $51.4 \%$ and $21.8 \%$ across the waves. The proportion marrying at younger ages that were in farming/manual jobs increased with time in Zambia while other countries presented mixed results.

Almost one-third of respondents aged $\leq 14$ years have experienced sexual intercourse before they attained or married at 17 in Zambia and Kenya across the years surveyed. In Ghana, 12.9\%, $13.0 \%$ and $14.0 \%$ have similar experience in 1990/1999, 2000/2009 and 2010/2014 respectively. Relatively, $50 \%$ of girls aged 15-19 years have had sex before marrying at age $\leq 17$. The results revealed declining trends in the proportion of rural dwellers marrying at lower age group (age $\leq 17$ ) between 1990/1999 and $2010 / 2014$. Most girls in rural areas in Zambia married before the age of 18 in 1990/1999, the proportion that later declined to $66.4 \%$ and $63.1 \%$ in 2000/2009 and 2010/2014 respectively. Ghana and Kenya distribution by this variable also revealed a declining trend.

The results of the Cox proportional hazards regression analysis used in the multivariate level are presented in Table 3. Each model represents the Cox 3570 proportional hazard regression for each of the waves (1990/1999, 2000/2009 and 2010/2014). The hazard models revealed that all education attainment categories are positively related and statistically significant to risk of marrying at early age ( $\leq 17$ years) in all the models. In the second and third waves, the finding indicated that women with higher level of education, were at lower risk of marrying at early age $(\leq 17$ years) and the results were statistically significant at $p<0.005$.

Comparing the women with education, especially those that have tertiary education with those without formal education (i.e. reference category), the result revealed that those with tertiary education have increasing lower risk of marrying at early age $(\leq 17)$ from (HR: 0.34, Cl: 0.30-0.39) in 1990/I999 to (HR $=0.39, \mathrm{Cl}: 0.36-0.43)$ in $2000 / 2009$ and (HR: 0.36, $\mathrm{Cl}$ : $0.34-0.37$ ) in 2010/2014. Therefore, the probability of marrying at early age seems to be decreasing with higher education. Also, women with secondary education have lower risk of marrying at early age compared to women without education. The hazard ratios across the waves for secondary education revealed the following: HR: $0.19, \mathrm{Cl}: 0.16-$ 0.25, HR: 0.60, Cl: 0.57-0.63 and (HR: 0.5I, Cl: $0.50-$ 0.53 in 1990/1999, 2000/2009 and 2010/2014, respectively. In the 1990/1999 results, while women with primary education are less likely to marry at early age in 1990/1999 (HR: 0.50, Cl: 0.42-0.6I) compared to women without formal education, they were less likely to marry at early age in $2010 / 2014$ (HR: 0.90, Cl: 0.88-0.93) compared to the reference category.

The impact of religious affiliations was relatively the same in both wave 2 and 3 . In the 1990s, those with Islamic and traditional religion affiliates have higher risk of marrying at younger age $(\leq I 7)$ compared to women who practice Christianity (i.e. reference category). The hazard ratio indicated (HR: 2.33, 95\% $\mathrm{Cl}:$ I.23-4.43) and (HR: I.0I, Cl: 0.532.32). Also, apart from the professionals who were less likely to marry at an early age in the 1990/1999, women in farming and sales/service occupations or live in rural areas have higher risk ratio of marrying at early age in this same period (1990/1999). However, in $2010 / 2014$, women who practice Islamic religion have lower risk of marrying at early age (HR: 0.84, $\mathrm{Cl}$ 0.77-0.92) while women who practice Christianity also demonstrated lower risk of marrying at younger age with hazard ratio of (HR: $0.73, \mathrm{Cl}$ : $0.69-0.76)$ in $(2010 / 2014)$. Similarly, those that http://aps.journals.ac.za 
practice traditional religion are also $24 \%$ less likely to marry at younger age compared to individual women in the reference category in the last wave (HR: 0.76 , Cl: 0.64-0.85).

Although wealth index was not captured in the dataset in the first round of surveys used in this study, the results of the last two waves (2000/2009 and 2010/2014) indicated that the hazard risk ratio decreases as the household wealth status improves. Women in the middle household wealth status have lower risk of marrying at younger age (with HR: 0.97 and Cl: 0.93-I.02) in 2000/2009 and (HR: 0.94, Cl: 0.92-0.97) in 2010/2014, compared to the reference category. Women from rich households demonstrated lower risk ratio of marrying at younger age (HR: 0.86, Cl: $0.8 \mathrm{I}-0.90)$ and (HR: 0.87, Cl: 0.840.89 ) in both 2000/2009 and 2010/2014 (respectively) compared to women from the poorer households. The hazard ratio for rural residence was relatively stagnated (at $H R=1.02$ ) in both
$1990 / 1999$ and $2000 / 2009$, indicating that, women that live in rural area have high risk ratio ( $2 \%$ more) of marrying at younger age compared to those in the urban centres as indicated by hazard ratio results (HR: I.02, Cl: 0.42-2.46) and (HR: I.02, Cl: 0.97I.07) for the two early waves. However, it was (HR: I.08, Cl: I.06-I.II) in 2010/20I4. At occupational level, the hazard risk ratios were higher among women in sales/services jobs $74 \%$ (HR: I.74, Cl: I.46-2.I I), (HR: I.I2, Cl: 0.97-I.29) and (HR: I.I8, Cl: I.I3-I.24) in 1990/1999, 2000/2009 and 2010/2014 respectively. The women farmers were $18 \%$ (in 1990/1999), 7\% (in 2000/2009) and 8\% (in $72010 / 2014)$ more likely to marry at younger age compared to unemployed (the reference category) as indicated by the hazard ratios for these periods. While all occupational categories were statistically significance at the third wave, none was significant at the second wave. 
Table 2. Percentage distribution of girl-child (aged $\leq 17)$ marrying and selected variables

\begin{tabular}{|c|c|c|c|c|c|c|c|c|c|}
\hline \multirow{2}{*}{$\begin{array}{l}\text { Waves } \\
\text { Countries }\end{array}$} & \multicolumn{3}{|c|}{ Wave I (1990-I999) } & \multicolumn{3}{|c|}{ Wave I (2000-2009) } & \multicolumn{3}{|c|}{ Wave I (20I0-20I4) } \\
\hline & Zambia & Ghana & Kenya & Zambia & Ghana & Kenya & Zambia & Ghana & Kenya \\
\hline Selected variables & 327 & 1614 & 2345 & 2774 & 1397 & 2311 & 5738 & 2307 & 8453 \\
\hline \multicolumn{10}{|l|}{ Education } \\
\hline No Education & 24.5 & 44.0 & 25.0 & 15.7 & 40.7 & 28.8 & 13.9 & 41.6 & 25.4 \\
\hline Primary & 70.0 & 19.7 & 66.1 & 68.9 & 27.6 & 62.3 & 64.8 & 24.6 & 62.7 \\
\hline Secondary & 5.5 & 35.6 & 8.7 & 14.6 & 31.0 & 8.3 & 20.7 & 32.9 & II.I \\
\hline Tertiary & - & 0.7 & 0.1 & 0.8 & 0.7 & 0.7 & 0.6 & 0.9 & 0.9 \\
\hline \multicolumn{10}{|l|}{ Religion Affiliation } \\
\hline Christianity & 99.8 & 68.2 & 99.9 & 98.3 & 67.7 & 99.7 & 99.0 & 70.5 & 99.6 \\
\hline Islam & - & 14.5 & - & - & 17.5 & - & - & 21.0 & - \\
\hline Traditional & 0.2 & 17.3 & 0.1 & 1.7 & 14.7 & 0.3 & 1.0 & 8.5 & 0.4 \\
\hline \multicolumn{10}{|l|}{ Occupation } \\
\hline Not working & 68.5 & 18.8 & 63.9 & 15.6 & 51.4 & 51.0 & 40.7 & 21.8 & 71.8 \\
\hline Professionals & 0.6 & 1.7 & 2.1 & 1.5 & 1.2 & 19.5 & 0.6 & 2.0 & 7.4 \\
\hline Clericals/services & 21.8 & 58.3 & 28.9 & 69.2 & 30.3 & 9.8 & 28.2 & 56.5 & 11.0 \\
\hline Farming/Manuals & 9.1 & 21.2 & 5.2 & 13.6 & 17.1 & 19.7 & 30.5 & 19.7 & 9.8 \\
\hline \multicolumn{10}{|l|}{ Age at Ist sex } \\
\hline Ist union & 17.8 & 27.6 & 27.3 & 38.2 & 24.8 & 24.5 & 47.3 & 47.1 & 39.1 \\
\hline$<15$ years & 29.1 & 12.9 & 28.6 & 14.9 & 13.0 & 20.6 & 12.0 & 14.0 & 21.7 \\
\hline $15-19$ years & 52.8 & 57.9 & 43.0 & 46.0 & 59.9 & 52.9 & 39.8 & 37.7 & 38.4 \\
\hline 20 \& above & 0.3 & 1.3 & I.I & 0.9 & 2.1 & 2.0 & 0.9 & 1.2 & 0.8 \\
\hline \multicolumn{10}{|l|}{ Residence } \\
\hline Urban & - & 27.4 & 15.4 & 33.6 & 30.2 & 21.1 & 36.9 & 36.2 & 30.9 \\
\hline Rural & 100.0 & 72.6 & 84.6 & 66.4 & 69.8 & 78.9 & 63.1 & 63.8 & 69.1 \\
\hline
\end{tabular}

Source: Computed from selected DHS datasets of Ghana, Kenya and Zambia (1990-2014)

Table 3: Hazard ratios of female age at first marriage in sub-Saharan Africa (1990-2014)

\begin{tabular}{|c|c|c|c|c|c|c|c|c|c|}
\hline Variables & Wave I & & & Wave 2 & & & Wave 3 & & \\
\hline $\begin{array}{l}\text { Education } \\
\text { No Education }\end{array}$ & $\begin{array}{c}\text { HR } \\
(\mathrm{RC})\end{array}$ & $P>|z|$ & $95 \% \mathrm{Cl}$ & HR & $P>|z|$ & $95 \% \mathrm{Cl}$ & HR & $P>|z|$ & $95 \% \mathrm{Cl}$ \\
\hline Primary & 0.5024 & 0.000 & $0.42-0.61$ & 0.9225 & 0.001 & $0.88-0.96$ & 0.9067 & 0.000 & $0.88-0.93$ \\
\hline Secondary & 0.1966 & 0.000 & $0.16-0.25$ & 0.6034 & 0.000 & $0.57-0.63$ & 0.5134 & 0.000 & $0.50-0.53$ \\
\hline Tertiary & 0.3405 & 0.000 & $0.30-0.39$ & 0.3888 & 0.000 & $0.36-0.43$ & 0.3599 & 0.000 & $0.34-0.37$ \\
\hline \multicolumn{10}{|l|}{ Religion } \\
\hline $\begin{array}{l}\text { Christianity } \\
\text { Islam }\end{array}$ & $\begin{array}{c}(\mathrm{RC}) \\
2.3327\end{array}$ & 0.010 & I.23-4.43 & 0.8396 & 0.000 & $0.77-0.92$ & 0.7313 & 0.000 & $0.69-0.76$ \\
\hline Others & 1.0109 & 0.782 & $0.53-2.32$ & $0.957 \mid$ & 0.522 & $0.83-1.09$ & 0.7364 & 0.000 & $0.64-0.85$ \\
\hline \multicolumn{10}{|l|}{ Wealth status } \\
\hline Moderate & $\mathrm{n} / \mathrm{a}$ & $\mathrm{n} / \mathrm{a}$ & $\mathrm{n} / \mathrm{a}$ & 0.9711 & 0.230 & $0.93-1.02$ & 0.9437 & 0.000 & $0.92-0.97$ \\
\hline Rich & $\mathrm{n} / \mathrm{a}$ & $\mathrm{n} / \mathrm{a}$ & $\mathrm{n} / \mathrm{a}$ & 0.8555 & 0.000 & $0.8 I-0.90$ & 0.8667 & 0.000 & $0.84-0.89$ \\
\hline $\begin{array}{l}\text { Occupation } \\
\text { Unemployed }\end{array}$ & $(\mathrm{RC})$ & & & & & & & & \\
\hline Sales/Services & 1.7389 & 0.000 & $1.46-2.11$ & 1.1199 & 0.113 & $0.97-1.29$ & 1.1820 & 0.000 & I.13-I.24 \\
\hline Farming & 2.1789 & 0.000 & $1.85-2.57$ & 1.0688 & 0.348 & $0.93-I .23$ & 1.0832 & 0.000 & $1.04-1.13$ \\
\hline Professional & 0.6929 & $0.7 \mid 4$ & $0.97-4.95$ & 0.9932 & 0.925 & $0.86-I .15$ & 1.0559 & 0.040 & $1.00-1.11$ \\
\hline $\begin{array}{l}\text { Residence } \\
\text { Urban }\end{array}$ & $(\mathrm{RC})$ & & & & & & & & \\
\hline Rural & 1.0227 & 0.960 & $0.425-246$ & 1.0186 & 0.448 & $0.97-1.07$ & 1.0814 & 0.000 & $1.06-1.11$ \\
\hline
\end{tabular}

Source: Computed from DHS, 1990-20I4. n/a = Data not available; RC= reference category 


\section{Discussion}

The study provided empirical results from crosssectional surveys at different points in the 24 years period on the risk of marrying at early age among women in Ghana, Kenya and Zambia. Notwithstanding the existence of country-by-country studies on determinants of age at marriage (Goldstein \& Kenney, 200I; Jones, 20I2; Zwang, 2004) or studies on the economic implications of late marriage (Andreev, Kantorová, \& Bongaarts, 2013; Bongaarts, 2010; Brown, 2007; Cancian \& Reed, 2008; Gupta, 20I I; Okogu, 20I I), a recent single trends analysis of female age at first marriage covering three regions of Africa (western, eastern and southern), for relatively two decades, is not only novel but rare. The relevant of interventions through the child-marriage market as espoused in this study could be crucial insights for reducing the menace of child bribes/marriages in subSaharan Africa as a whole. The study could also give the young girls the understanding of the implications of under-age marriage, and the need to resist vulnerability to the risk of early marriage. The study could be regarded as update on several individual and aggregate data sources for 50 years (Garenne, 2004) which may not reveal the reality, especially due to mortality level and the level of instability in several aspects of the economy, politics including data management. In addition, the use of standardised national representative data and the analysis by survey horizons positions this study differently from existing individual country-based studies (Cancian \& Reed, 2008; Garenne et al., 20I I; Glick \& Landau, 1950; Goldstein \& Kenney, 200I; Jones, 20I2; Psaki, 2015; Zwang, 2004)

The overall results from this study pointed to the fact that women age at first marriage is rising though at a slow pace in Zambia, Ghana and Kenya, and by extension, across sub-Saharan regions. Empirical revelation from the study is that the proportion that marries at early age is decreasing in all countries of study, though not at a uniform rate. Women median age at first marriage increased consistently from $1990 / 1999$ to $2010 / 2014$, however in Zambia (as exceptional case), it reduced in 2000/2009 but thereafter increased in $2010 / 2014$. The decline in the proportion of girl-child experiencing sex at age $\leq 15$ could also reduce the risk of entering into early marriage.

There are elements of religion support for early marriage in the countries of study. The results of analysis where all religion affiliations became statistically significant in the last wave suggested the reality of this support in the current dispensation $(2010 / 2014)$. Marriage, religion and culture in subSaharan Africa are intertwined and higher values are still placed on the girl-child virginity as tools for http://aps.journals.ac.za procuring good honour to the family and higher bride price (Awusabo-Asare \& Annim, 2008; Bingenheimer, 2010; Delius \& Glaser, 2004; Gurmu, \& Etana, 20I4; Ikpe, 2004; Odimegwu, 2005; Reda \& Lindstrom, 20I4). Thus, families could be culturally compelled to give away a little-child for marriage before her real exposure to pre-marital sexual activities in order to receive the perceived honour and high bride price. While other studies have confirmed that formal education plays significant role in early marriage (Berrington, Stone, \& Beaujouan, 2015; Indongo \& Pazvakawamba, 20I5; UNICEF, 2005), the results from this study statistically supported only tertiary education as a crucial determinant for later-age marriages in Ghana, Kenya and Zambia, the result which can also be generalised to cover other subSaharan African countries. This finding also contradicted other studies that have recommended compulsory primary (or basic) education as panacea for early marriage (Brown, 2007; International Center for Research on Women [ICRW], 2015; Martin \& Juarez, 1995; Potts, Gidi, Campbell, \& Zureick, 20II; UNICEF, 2005; Wright, 2007). The study also provided evidence that there is no common age at entry into marriage in sub-Saharan Africa.

The study demonstrated that increase in wealth reduces the propensity to marry early (age $\leq 19$ years). This information is also validated by its statistical significant $(P<0.005)$ and could be a pointer to the need for women empowerment in terms of job creation or opportunities in the countries of study to raise women age at first marriage. This finding is in tandem with the finding from Garenne (2004) and Garenne et al (20I I), where income was identified as main factor of increasing median age at marriage (Garenne, 2004; Garenne et al., 20ll). Although, the professional occupation distribution could be directly attached to high educational attainment, a distinct support for girls to take professional jobs could also make a significance contribution to the lower hazard risk of entering into early marriage. Individuals certified as professionals must have (in most cases) attained tertiary education, spending years in schooling or training which makes marriage to be voluntarily or inadvertently delayed. The relative high risk of marriage at early age among women in rural areas is an indication that early marriage is still in vogue in the rural communities of the study locations.

\section{Limitations of the study}

The omission of wealth index in the first dataset (199|-2000) selected for this study circumvented a long broad overview of odds ratios of women 
marrying at a younger age with respect to selected variables in the 90 s.

\section{Conclusion and recommendations}

The study concludes that women age at first marriage is increasing in sub-Saharan Africa, though at a very slow rate and not in uniform proportion across Ghana, Kenya and Zambia. It highlighted that the relative risk of marrying at younger age reduces as education increases to tertiary level and also as wealth status changes. Leveraging on the theoretical model of the child-marriage market, the study specifically underscored the need to build support towards access to tertiary education, professional jobs which could empower the girl-child to reject or negotiate marriage offers until maturity ages and thereby delay marriage. While these supports raise the opportunity cost of marriage, it will also release the girls for productive economic opportunities. The import of tertiary education cannot be overemphasized in stemming under-age marriage while gainful occupation could double as empowerment tool as well as a means of raising women age at first marriage. The observed irregular pattern of women age at first sex among the under15 is fundamental to the formulation of policy and policy directions. Overall, the reduction in girl-child marriage have potential to reduce girl-child vulnerability to STIs/HIV and AIDS and possible delivery of post-2015 sustainable development agenda. The study therefore supports the use of child-marriage market model to reduce child marriage but through girl's access to tertiary education and professional occupation empowerment.

\section{Acknowledgements}

The author appreciate MEASURE DHS for permission to access the dataset used for this study and the University of the Witwatersrand, Johannesburg, South Africa, for providing resources and facilities that enhanced the preparation of the manuscript.

The author would also like to gratefully acknoweldge the supports and comments from the 2016 Family Demography in African and Post-2015 Development Agenda Conference, hosted by Demography and Population Studies and cosponsored by the NRF CoE in Human Development, NRF Conference Fund and NIHSS.

\section{References}

Adebowale, S. A., \& Palamuleni, M. E. (20/4). Childbearing dynamics among married women of reproductive age in Nigeria: re-affirming the role of education. Etude de La Population Africaine, 27(2 Suppl.), 30I-3I8.

African Union. (20I5a). AGENDA 2063. Report of the Commission on the African Union Agenda 2063. The Africa We Want in 2063. ASSEMBLY OF THE UNION Twenty-Fourth Ordinary Session 30 -3I January 2015 Addis Ababa, ETHIOPIA. African Union, Addis Ababa, Ethiopia.

Retrieved from http://www.fasngo.org/assets/files/25\%20GIMAC/ Final\%20docs/Report\%20of\%20the\%20Commis sion.pdf

African Union. (20I5b). Common African Position (CAP) on the Post-2015 Development Agenda. African Union, Addis Ababa, Ethiopia. Retrieved from

http://www.who.int/pmnch/development_agenda. pdf?ua $=1$

Alcalá, M. J., \& Leidl, P. (2006). UNFPA State of world population, 2006. United Nations Population Fund.

Andreev, K., Kantorová, V., \& Bongaarts, J. (20/3). Demographic Components of Future Population Growth. Population Division, Technical Paper No. 2013/3. Population Division, Department of Economic and Social Affairs, United Nations, New York. USA.

Awusabo-Asare, K., \& Annim, M. S. K. (2008). Wealth status and risky sexual behaviour in Ghana and Kenya. Applied Health Economics and Health Policy, 6(I), 27-39.

Berrington, A., Stone, J., \& Beaujouan, E. (2015). Educational differences in timing and quantum of childbearing in Britain: a study of cohorts born 1940-1969. Author's Original, I-39.

Bhat, P. M., \& Halli, S. S. (1999). Demography of bride price and dowry: Causes and consequences of the Indian marriage squeeze. Population Studies, 53(2), 129-148.

Bigombe, B., \& Khadiagala, G. (2003). Major trends affecting families in sub-Saharan Africa. New York: United Nations.

Bingenheimer, J. B. (20I0). Men's Multiple Sexual Partnerships in 15 Sub-Saharan African Countries: Sociodemographic Patterns and Implications. Studies in Family Planning, 4I(I), I-I7.

Bongaarts, J. (1983). The proximate determinants of natural marital fertility. Determinants of Fertility in Developing Countries: A Summary of Knowledge, (I5), 85.

Bongaarts, J. (2007). Late marriage and the HIV epidemic in sub-Saharan Africa. Population Studies, 6I(I), 73-83.

Bongaarts, J. (2010). The causes of educational differences in fertility in sub-Saharan Africa. Vienna Yearbook of Population Research, 31-50. 
Brown, G. F. (2007). 4 Tunisia: The Debut of Family Planning. The Global Family Planning Revolution: Three Decades of Population Policies and Programs, 59.

Budlender, D., Chobokoane, N., \& Simelane, S. (2004). Marriage patterns in South Africa: methodological and substantive issues. Southern African Journal of Demography, I-25.

Cancian, M., \& Reed, D. (2008). Family structure, childbearing, and parental employment: Implications for the level and trend in poverty. Citeseer.

Chersich, M. F., Luchters, S., Ntaganira, I., Gerbase, A., Lo, Y.-R., Scorgie, F., \& Steen, R. (20I3). Priority interventions to reduce HIV transmission in sex work settings in sub-Saharan Africa and delivery of these services. Journal of the International AIDS Society, I6(I).

Delius, P., \& Glaser, C. (2004). The myths of polygamy: a history of extra-marital and multipartnership sex in South Africa. South African Historical Journal, 50(I), 84-I I4.

Garenne, M. (2004). Age at marriage and modernisation in sub-Saharan Africa. Southern African Journal of Demography, 9(2), 59-79.

Garenne, M. L., Leclerc, P. M., \& Matthews, A. P. (20II). Parameterisation of the transition to first marriage with the Picrate model. Southern African Journal of Demography, I2(I), 109-1 24.

Glick, P. C., \& Landau, E. (1950). Age as a Factor in Marriage. American Sociological Review, 15(4), 517-529.

Goldstein, J. R., \& Kenney, C. T. (200I). Marriage delayed or marriage forgone? New cohort forecasts of first marriage for US women. American Sociological Review, 506-519.

Gupta, M. (20I I). Impact of Early Marriage in Fertility among SC, ST and Tea-Tribe Communities of Dibrugarh District, Assam, India: An Analysis through Logistic Regression. International Journal of Educational Planning \& Administration, I, No. 3, $21 \mid-215$.

Gurmu, E., \& Etana, D. (20/4). Age at First Marriage and First Birth Interval in Ethiopia: Analysis of the Roles of Social and Demographic Factors. Etude de La Population Africaine, 28(3), I332-I 344.

Gyepi-Garbrah, B., Nichols, D. J., \& Kpedekpo, G. M. (1985). Adolescent fertility in sub-Sahara Africa: An overview (Vol. I). Newcastle Publishing Company.

Hindin, M. J., \& Fatusi, A. O. (2009). Adolescent sexual and reproductive health in developing countries: an overview of trends and interventions. International Perspectives on Sexual and Reproductive Health, 35(2), 58-62.
Huq, M. N., \& Cleland, J. (1990). Bangladesh Fertility Survey 1989 (main report).

ICSU, \& ISSC. (20I5). Review of the Sustainable Development Goals: the science perspective. International Council for Science (ICSU), International Social Science Council (ISSC), Paris. Retrieved from http://www.icsu.org/publications/reports-andreviews/review-of-targets-for-the-sustainabledevelopment-goals-the-science-perspective2015/SDG-Report.pdf

Ikpe, E. B. (2004). Human sexuality in Nigeria: A historical perspective (pp. 10-38). Presented at the Understanding Human Sexuality, Seminar Series, Citeseer.

Indongo, N., \& Pazvakawamba, L. (2015). Perceptions of Women on Marriage in Namibia. Psychology, 6(II), 14I3-1420.

International Center for Research on Women [ICRW]. (20I5). Child Marriage and Health. International Center for Research on Women [ICRW]. Retrieved from http://www.icrw.org/files/images/Child-MarriageFact-Sheet-Health.pdf

Isiugo-Abanihe, U. C., Erinosho, O., Ushie, B., Aderinto, A., Sunmola, G., \& Joseph, R. (20I2). Age of sexual debut and patterns of sexual behaviour in two local government areas in southern Nigeria. African Journal of Reproductive Health, 16(4), 8I-94.

Isiugo-Abanihe, Uche C. (1995). Bridewealth, marriage and fertility in the East-Central states of Nigeria. Genus, I5I-I78.

Islam, M. N., \& Islam, M. M. (1993). Biological and behavioural determinants of fertility in Bangladesh: 1975-1989. Asia-Pacific Population Journal, 8(I), $3-18$.

Jones, G. (20/2). Late marriage and low fertility in Singapore: The limits of policy. The Japanese Journal of Population, IO(I), 89-10I.

Keller, A. B. (1973). Psychological determinants of family size in a Mexican village. Merrill-Palmer Quarterly of Behavior and Development, 19(4), 289-299.

Lehrer, E. L. (2008). Age at marriage and marital instability: revisiting the Becker-Landes-Michael hypothesis. Journal of Population Economics, $2 I(2), 463-484$.

Machiyama, K. (20I I). A re-assessment of fertility trends in 17 Sub-Saharan African countries. Doctoral thesis, London School of Hygiene \& Tropical Medicine. London School of Hygiene \& Tropical Medicine, London. Retrieved from https://researchonline.Ishtm.ac.uk/9899/2///Machi yama_PhD_I5.II.20II.pdf 
Martin, T. C., \& Juarez, F. (1995). The impact of women's education on fertility in Latin America: Searching for explanations. International Family Planning Perspectives, 52-80.

Mensch, B. S., Grant, M. J., \& Blanc, A. K. (2006). The Changing Context of Sexual Initiation in subSaharan Africa. Population and Development Review, 32(4), 699-727.

Mensch, B. S., Singh, S., \& Casterline, J. B. (2005). Trends in the timing of first marriage among men and women in the developing world. The Changing Transitions to Adulthood in Developing Countries: Selected Studies, I I8-7I.

Moghadam, V. M. (2004). Patriarchy in transition: Women and the changing family in the Middle East. Journal of Comparative Family Studies, I37162.

Mubiru, F., Atuhaire, L. K., Lubaale, Y. M., \& Wamala, R. (20|6). Predictors of time to first birth after first marriage among women in Uganda. African Population Studies, 30 (2 Suppl), 2482-2494.

Murray, C. E., King, K., \& Crowe, A. (20/6). Understanding and Addressing Teen Dating Violence Implications for Family Counselors. The Family Journal, 24(I), 52-59.

National Population Commission (NPC) [Nigeria], \& ICF International. (2013, October). Nigeria Demographic and Health Survey 2013. Preliminary Report. National Population Commission (NPC) [Nigeria], Abuja and ICF International, Rockville, Maryland, USA. Retrieved from https://dhsprogram.com/pubs/pdf/FR293/FR293.p df

Odimegwu, C. (2005). Influence of religion on adolescent sexual attitudes and behaviour among Nigerian university students: affiliation or commitment? African Journal of Reproductive Health, I25-I40.

Odimegwu, C., Bamiwuye, O. S., \& Adedini, S. A. (2015). Gender-based violence as a new proximate determinant of fertility in sub-Saharan Africa. Southern African Journal of Demography, I6(I), 87.

Okogu, J. (20I I). Family size and its socio-economic implications on the inhabitants of Delta State, Nigeria. International Journal of Economic Development Research and Investment, 2, No. 3, 128-133.

Pettifor, A. E., Van Der Straten, A., Dunbar, M. S., Shiboski, S. C., \& Padian, N. S. (2004). Early age of first sex: a risk factor for HIV infection among women in Zimbabwe. Aids, I8(I0), I435-1442.

Population Reference Bureau [PRB]. (20I5). 2015 World Population Data Sheet. Population Reference Bureau, Washington, DC.
Potts, M., Gidi, V., Campbell, M., \& Zureick, S. (20l I). Niger: Too little, too late. International Perspectives on Sexual and Reproductive Health, 37(2), 95-101.

Psaki, S. R. (20I5). Addressing early marriage and adolescent pregnancy as a barrier to gender parity and equality in education. Background Paper for EFA Global Monitoring Report.

Reda, A. A., \& Lindstrom, D. (20I4). Recent trends in the timing of first sex and marriage among young women in Ethiopia. Etude de La Population Africaine $=$ African Population Studies, 28(2 Suppl), II 57.

Rezai-Rashti, G. M., \& Moghadam, V. M. (20II). Women and higher education in Iran: What are the implications for employment and the "marriage market"? International Review of Education, 57(3-4), 4I9-44I.

UNICEF. (200I). The State of the World's Children 200I. Editorial and Publications Section, Division of Communication, UNICEF, New York. Retrieved from www.unicef.org/.../The\%20State\%20of\%20the \%20World's\%20Children\%20200I.pdf

UNICEF. (2005). Early Marriage A Harmful Traditional Practice A Statistical Exploration 2005. UNICEF.

UNICEF. (20II). The State of the World's Children 20I I-Executive Summary: Adolescence an Age of Opportunity. United Nations Children's Fund (UNICEF). Retrieved from https://www.unicef.org/adolescence/files/SOWC_ 20I I_Main_Report_EN_020920I I.pdf

UNICEF. (20I4a). ending child marriage: progress and prospects. New York: UNICEF.

UNICEF. (20I4b). The state of the world's children 2015: Reimagine the future: Innovation for every child. Division of Communication, United Nations Children's Fund (UNICEF), New York, I-I 24.

United Nations. (20/4). Concise Report on the World Population Situation in 2014. Department of Economic and Social Affairs, Population Division, United Nations, New York.

United Nations Children's Fund [UNICEF]. (20I5). A Profile of Child Marriage in Africa. Data and Analytics Section of UNICEF for the African Girls' Summit on Ending Child Marriage, United Nations Children's Fund [UNICEF], New York. 2015. Retrieved from http://data.unicef.org/corecode/uploads/document 6/uploaded_pdfs/corecode/UNICEF-ChildMarriage-Brochure-High-Single_246.pdf

United Nations Population Fund [UNFPA]. (2004). Programme of Action Adopted at the International Conference on Population and Development, Cairo, September 5-13, 1994. 
E/25,000/2004. United Nations Population Fund. Retrieved from https://www.unfpa.org/sites/default/files/eventpdf/PoA_en.pdf

Wahhaj, Z. (20I5). A theory of child marriage. University of Kent. Http://Zwahhaj. Nfshost. Com/Child\% 20Marriage\% 20Draft. Pdf (Accessed November 13, 20/3).

World Health Organization, UNAIDS, \& UNICEF. (20II). Global HIV/AIDS Response: Epidemic update and health sector progress towards Universal Access. Progress Report 201I. Retrieved from http://apps.who.int/iris/bitstream//0665/44787/I/ 9789241502986_eng.pdf

World Vision, Henderson, R., \& Jones, M. (2016). Ending Child Marriage by 2030 Tracking Progress and Identifying Gaps. POLICY Paper July 2016. World Vision UK. Retrieved from http://www.girlsnotbrides.org/wpcontent/uploads/2016/07/Ending_Child_Marriage_ by_2030.pdf

Wright, N. H. (2007). Early Family Planning Efforts in Sri Lanka. The Global Family Planning Revolution: Three Decades of Population Policies and Programs, 34I.

You, D., Hug, L., \& Anthony, D. (20I5). UNICEF report Generation 2030 Africa calls upon investing in and empowering girls and young women. Reproductive Health, I2(I), I-4.

Zwang, J. (2004). Perceptions and attitudes towards late marriage and premarital fertility in rural South Africa. IFAS Working Paper Series/Les Cahiers de I'IFAS, 4, 6Ip. 